\title{
Aonla (Emblica officinalis Gaertn.) Based Fermented Beverages
}

\author{
M. Chirag Reddy ${ }^{*}$, K.N. Sreenivas, G.S. Manjula, M. Karan and \\ H. Mohamad Tayeeb Ulla
}

Department of Post-Harvest Technology, College of Horticulture, GKVK Post, UHS Campus, Bengaluru, Karnataka, India

*Corresponding author

\begin{tabular}{|c|c|}
\hline & A B S T R A C T \\
\hline Keywords & \multirow{4}{*}{$\begin{array}{l}\text { Blended and fermented aonla beverage was prepared by using different fruit } \\
\text { combination viz., sapota, pineapple and grapes. The total soluble solids (TSS) } \\
\text { were adjusted to } 14{ }^{\circ} \mathrm{B} \text { with mixing of raisin juice. The fermentation was carried } \\
\text { out for } 72 \text { hours using Saccharomyces cerevisiae var. ellipsoideus (MTCC 552). } \\
\text { The fermentate was transferred to pre sterilized glass bottles and pasteurized } \\
\text { before ageing. The chemical parameters of the blended beverage reveled that there } \\
\text { was an increase in alcohol and titratable acidity content, TSS, pH, ascorbic acid } \\
\text { content were decreased during ageing. Among different blending, combination of } \\
50 \% \text { each of grated aonla and grape must recorded } 8.70{ }^{\circ} \mathrm{B} \text { TSS, } 4.29 \mathrm{pH}, 7.85 \% \\
\text { total sugar, } 582.27 \text { (mg gallic acid equivalents } 100 \mathrm{ml}^{-1} \text { ) phenolic content, } 307.63 \\
\left(\mathrm{mg} \text { AAE } 100 \mathrm{ml}^{-1}\right) \text { total antioxidant content and } 3.29 \% \text { alcohol. The combination } \\
\text { was also rated superior }(7.5 \text { out of } 9 \text { point hedonic scale rating) by sensory panel. }\end{array}$} \\
\hline $\begin{array}{l}\text { Aonla, Fermented } \\
\text { beverage, TSS, pH, } \\
\text { sugars, Total } \\
\text { antioxidants, Total } \\
\text { phenols and } \\
\text { alcohol. }\end{array}$ & \\
\hline Article Info & \\
\hline $\begin{array}{l}\text { Accepted: } \\
\text { 29 September } 2017 \\
\text { Available Online: } \\
\text { 10 October } 2017\end{array}$ & \\
\hline
\end{tabular}

\section{Introduction}

Aonla (Emblica officinalis Gaertn.) is a subtropical fruit belonging to family Euphorbiaceae. It is extensively used in Ayurveda for its medicinal properties, since time immemorial. Direct consumption of aonla is less preferred because of its high acidity and astringent taste. Thermal processing makes the fruits lose vital phytochemicals such as ascorbic acid, polyphenols, antioxidants etc. An alternative method of processing like fermentation is boon in this regard. Further, to ward off misconception regarding drinking alcohol beverages, developments of products which are having less than 5 per cent alcohol using natural source of sugar, which is similar to many Ayurveda products, helps in better acceptance of the prepared products for enhanced health benefits. Therefore, blending of two or more fruit juices and their beverages are thought to be a convenient alternative for its utilization in order to have some value added fruit drinks which are of high quality in respect of sensory and nutritional aspects. So the preparation of blended beverage from grated aonla using raisin paste as the present technology of manufacturing wine from grapes is available. Keeping in view of the 
above, the current study was formulated to develop nutritional yet sensory acceptable fermented beverage from nutraceutical rich aonla with studying other fruits.

\section{Materials and Methods}

Fully matured, disease free, aonla fruits, Pineapple, Sapota and Grapes (Bangalore Blue) were obtained from the market for the experiment. Fruits were washed thoroughly in clean water and aonla were grated into small pieces in aonla greater machine. The selected sapota and pineapple fruits were weighed individually and were peeled using stainless steel knife. The edible fruit portion was cut into small rectangular slices after removing the core by using fruit corer in case of pineapple. Grapes were mashed by hands and then used for the experiment. Fruits were blended into different combination viz., $\mathrm{T}_{1}=$ Grated Aonla (100 per cent: Control); $\mathrm{T}_{2}=$ Grated Aonla (60 per cent) with Sapota Pulp (40 per cent); $\mathrm{T}_{3}=$ Grated Aonla (50 per cent) with Sapota Pulp (50 per cent); $\mathrm{T}_{4}=$ Grated Aonla (60 per cent) with Pineapple Pulp (40 per cent); $\mathrm{T}_{5}=$ Grated Aonla (50 per cent) with Pineapple Pulp (50 per cent); $\mathrm{T}_{6}=$ Grated Aonla (60 per cent) with Grape Must (40 per cent); $\mathrm{T}_{7}=$ Grated Aonla (50 per cent) with Grape Must (50 per cent) and the TSS of must was maintained at $14^{\circ} \mathrm{B}$ for all treatments using raisin juice. These treatments were evaluated for their bio-chemical composition during storage period and sensory qualities after three months of storage. The experiment was carried out with seven different treatments and five replications, using completely randomized design.

Aonla blended beverage was analyzed for $\mathrm{pH}$, TSS, sugars, total phenols, total antioxidant and alcohol content during three months of storage. Various physico-chemical characteristics of the blended beverage were analyzed as per the standard methods. Total soluble solids (\%) were measured using ATAGO pocket refractometer. Sugars present in the aonla blended beverage were estimated, following the method of Lane and Eynon described by Ranganna (1986) with some modifications using Fehling's solution A \& B and methylene blue as an indicator. The $\mathrm{pH}$ was measured using I Trans Bench top $\mathrm{pH}$ meter, after standardization with buffers of pH 4 and 9. Ethanol content was determined by spectrophotometric method (Caputi et.al., 1968) using potassium dichromate. The absorbance was taken at $600 \mathrm{~nm}$ in a spectrophotometer The standard curve was prepared using pure ethanol in concentrations ranging from 0 to 8 per cent and the of ethanol in the experimental sample were determined and expressed as per cent. The total phenols present in fermented beverage prepared from aonla blends were estimated using FRAP method given by Singleton and Rossi (1965). Here the Principle involved is Phenols react with the oxidizing agent phosphomolybdate in Folin-Ciocalteau reagent and form a blue colored complex, molybdenum blue which is measured at $700 \mathrm{~nm}$. The total antioxidants present in fermented beverage prepared from aonla blends were estimated using FRAP method given by Benzie and Strain (1996).

\section{Results and Discussion}

\section{Total soluble solids ( TSS $\left.^{\circ} \mathrm{B}\right)$}

Blended beverages of grated aonla (50\%) with grape must $(50 \%)-\mathrm{T}_{7}$ was found best and significant with higher TSS (8.70) whereas the lowest TSS (7.50) was observed in $\mathrm{T}_{1}$ - grated aonla (100 per cent - Control). TSS was decreased as the storage period advanced in all the treatments; this was due to conversion of sugars to alcohol by yeasts during fermentation and also consumption of sugars by yeast. Similar results were reported 
in grapes by Patil (1994) and Taskar (2007), the TSS content were decreased sharply from 23.0 to $8.20^{\circ}$ Brix during fermentation. Later the rate of fermentation was decreased but it continued at a much slower rate up to 8 days during which a decrease of 12.9 per cent TSS was noted. The increased TSS may be attributed to less alcohol content and decreased TSS during storage period this might be due to concentration of the nutrient resulted in higher alcohol yield and thus less TSS (Table 1).

\section{$\mathrm{pH}$}

A decreased in $\mathrm{p}^{\mathrm{H}}$ was observed in aonla blended beverages as the storage period increased. Treatment 7 \{Grated Aonla (50\%) with Grape Must $(50 \%)\}$ recorded higher $\mathrm{p}^{\mathrm{H}}$ (4.29), whereas, the lowest $\mathrm{p}^{\mathrm{H}}$ (4.20) was recorded in grated aonla (100 per cent, which was due to production of acid by yeast during the fermentation process. The results were in concurrence with the findings of Olasupo and Obayori (2003). These results were on par with the results of Bravo and Inigo (1989) that increased acidity would have resulted in decrease in $\mathrm{pH}$ at lower concentrations of sugar. Adsule et al., (1995) opined that the production of malic, lactic, citric, and tartaric acid resulted in decreasing the $\mathrm{pH}$ (Table 2).

\section{Reducing sugars (\%)}

Reducing sugars was found to decrease in storage period. Blended beverages of Grated Aonla (50\%) with Grape Must (50\%) - $\mathrm{T}_{7}$ was found to be significant with higher reducing sugar content. The lowest reducing sugar content was observed in $\mathrm{T}_{1}$ - Grated Aonla (100 per cent - Control). During storage, as the period advanced the reducing sugar content decreased. These results are in agreement with the results of Matapathi (2002) who studied the screening of wine yeasts and pomegranate cultivars for wine production and found reduction in per cent residual sugars content of pomegranate wine during 60 days of storage (Table 3 ).

\section{Total sugars (\%)}

A decreasing trend of total sugars was observed in the blended beverages. The total sugar content of the wine differed significantly among the treatments. $\mathrm{T}_{7}$ Grated Aonla (50 \%) with Grape Must (50\%) was found to be significant with higher sugars. The lowest was observed in $\mathrm{T}_{1}$ Grated Aonla (100 per cent - Control). During storage, as the period advanced the total sugar content also decreased. These results were similar to Bravo and Inigo (1989) who reported to notice that during ageing total sugars decreased and also Olasupo and Obayori (2003) monitored the process for changes in sugar content for $24 \mathrm{hr}$ interval during the 5 days of fermentation. The sugar content decreased significantly (Table 4).

\section{Total phenols (mg gallic acid equivalents $100 \mathrm{ml}^{-1}$ )}

The decreasing trend in the phenolic content was observed during the storage time. The phenolic content was recorded highest in the $\mathrm{T}_{1}$ - Grated Aonla (100 per cent - Control). There was significant difference between the treatments with respect to phenols. The lowest level of phenols was observed in the treatment $\mathrm{T}_{7}$ - Grated Aonla (50\%) with Grape Must $(50 \%)$. The results are on par with the results of Augustin (1987) where he found higher phenolic content in cashew apple wine. This might be due to high rate of fermentation releasing higher amounts of phenols and tannins. Various proteins including yeast cells become coated with tannin making such aggregates to settled down and give clarity to the wine. This result were supported by the study of Attri et al., (2009), they estimated the total phenols content in cashew apple wine was $152.08 \mathrm{mg} / \mathrm{l}$ after 10 days after fermentations (Table 5). 
Fig.1 Flow chart of preparation of aonla blended beverage

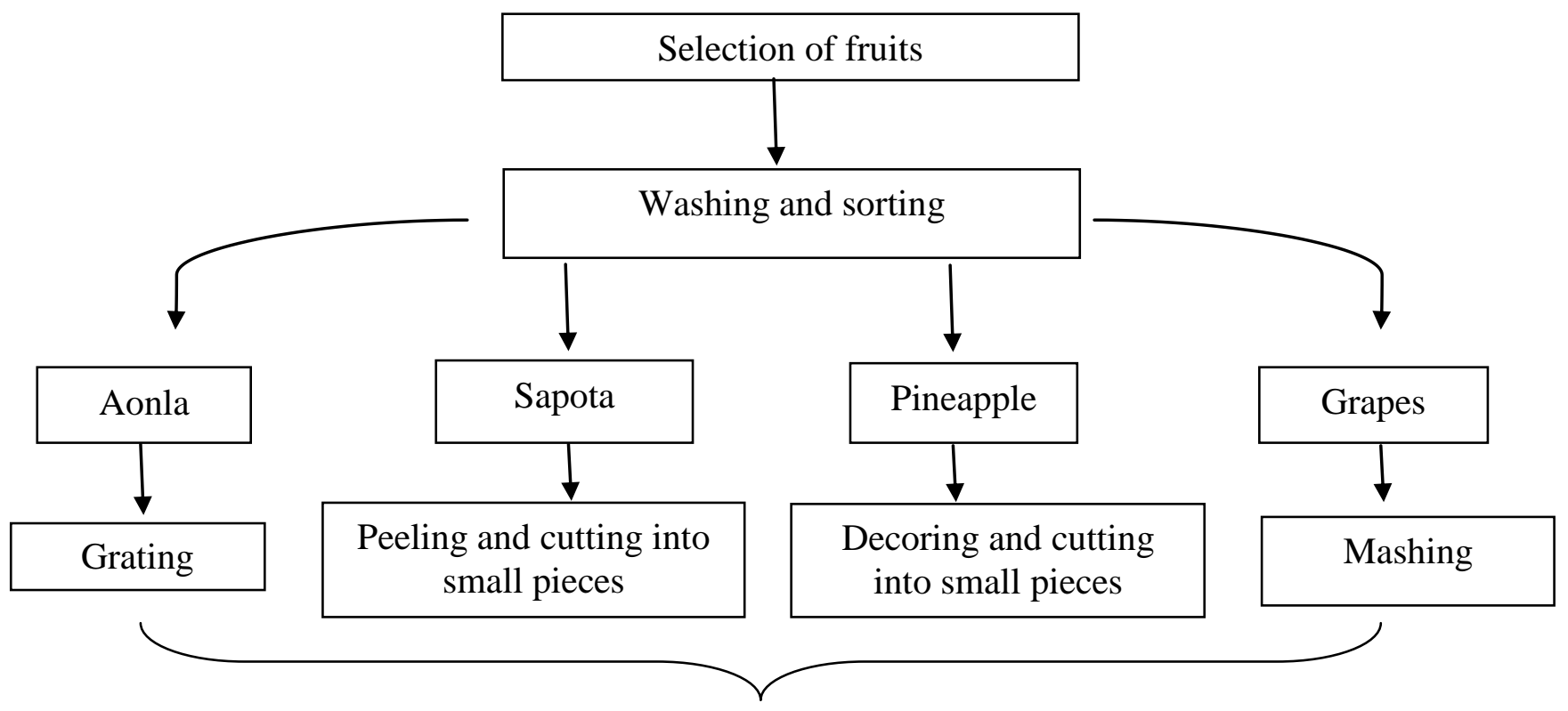

Fruits pulp were blended into the flasks

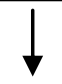

Raisin juice was added to make up the $\operatorname{TSS}\left(14^{\circ} \mathrm{B}\right)$ of the must

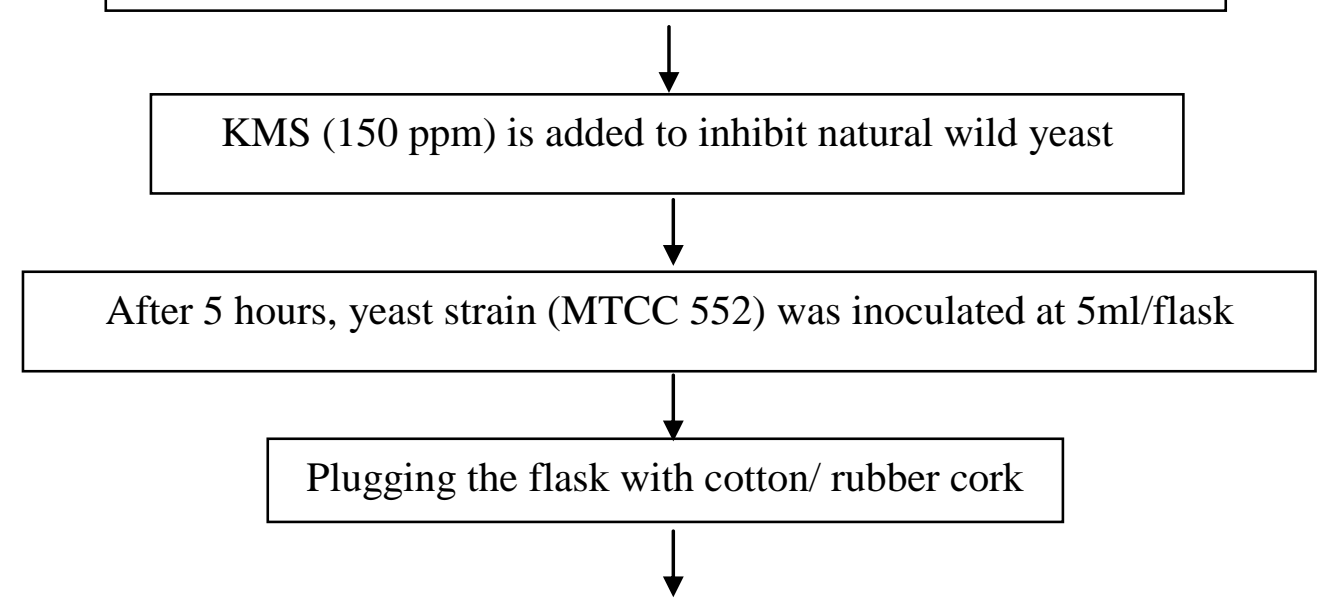

Fermented for 2 days and transferred the fermentate to pre sterilized glass bottles for ageing

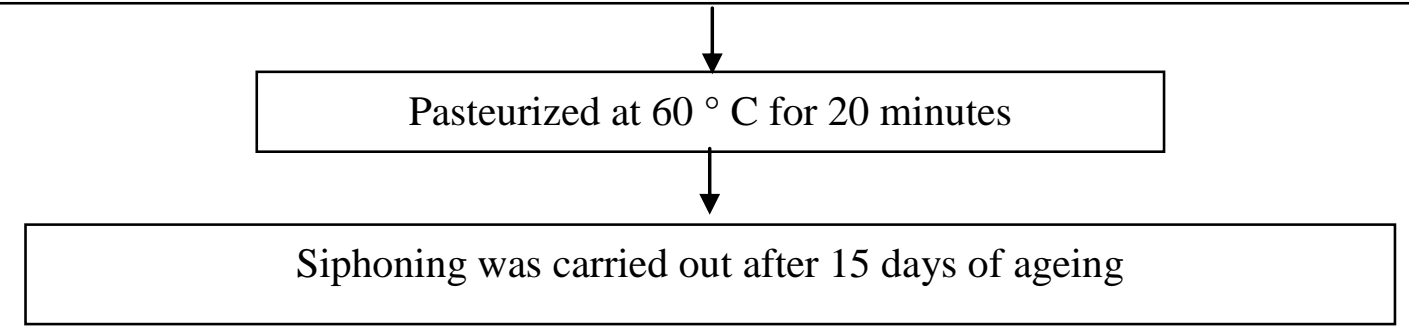


Table.1 Effect of different fruit pulp ratio on TSS $\left({ }^{\circ} \mathrm{B}\right)$ content of blended beverages during storage period

\begin{tabular}{|c|c|c|c|c|c|c|c|}
\hline TREATMENT & 0 Days & 15 Days & 30 Days & 45 Days & 60 Days & 75 Days & 90 Days \\
\hline $\mathrm{T}_{1}=$ Grated Aonla $(100 \%)-($ Control $)$ & 8.14 & 7.76 & 7.84 & 7.78 & 7.66 & 7.62 & 7.50 \\
\hline $\mathrm{T}_{3}=$ Grated Aonla (50 \%) with Sapota Pulp (50\%) & 8.68 & 8.44 & 8.24 & 8.10 & 7.94 & 7.84 & 7.74 \\
\hline $\mathrm{T}_{5}=$ Grated Aonla (50 \%) with Pineapple Pulp (50\%) & 9.36 & 8.82 & 8.88 & 8.72 & 8.62 & 8.56 & 8.44 \\
\hline $\mathrm{T}_{6}=$ Grated Aonla $(60 \%)$ with Grape Must (40 \%) & 8.80 & 8.58 & 8.40 & 8.22 & 8.14 & 8.02 & 7.90 \\
\hline $\mathrm{T}_{7}=$ Grated Aonla $(50 \%)$ with Grape Must (50 \%) & 9.56 & 9.38 & 9.14 & 9.06 & 8.98 & 8.82 & 8.70 \\
\hline F test & $* *$ & $* *$ & $* *$ & $* *$ & $* *$ & $* *$ & $* *$ \\
\hline
\end{tabular}

Table.2 Effect of different fruit pulp ratio on $\mathrm{p}^{\mathrm{H}}$ of blended beverages during storage period

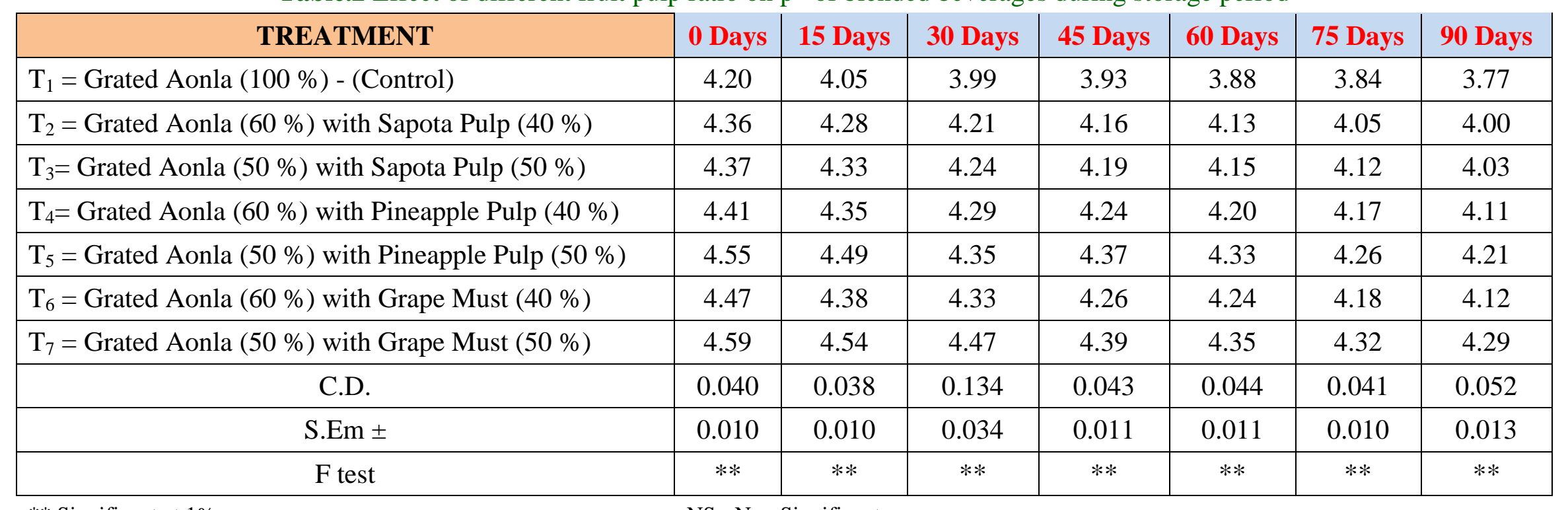


Table.3 Effect of different fruit pulp ratio on reducing sugars (\%) content of blended beverages during storage period

\begin{tabular}{|c|c|c|c|c|c|c|c|}
\hline TREATMENT & 0 Days & 15 Days & 30 Days & 45 Days & 60 Days & 75 Days & 90 Days \\
\hline $\mathrm{T}_{1}=$ Grated Aonla $(100 \%)-($ Control $)$ & 2.98 & 2.95 & 2.91 & 2.88 & 2.85 & 2.82 & 2.76 \\
\hline $\mathrm{T}_{2}=$ Grated Aonla $(60 \%)$ with Sapota Pulp (40\%) & 3.09 & 3.06 & 3.03 & 2.98 & 2.95 & 2.93 & 2.89 \\
\hline $\mathrm{T}_{3}=$ Grated Aonla (50 \%) with Sapota Pulp (50\%) & 4.18 & 4.17 & 4.15 & 4.13 & 4.09 & 4.05 & 3.97 \\
\hline $\mathrm{T}_{4}=$ Grated Aonla $(60 \%)$ with Pineapple Pulp (40\%) & 4.26 & 4.24 & 4.21 & 4.19 & 4.14 & 4.11 & 4.05 \\
\hline $\mathrm{T}_{5}=$ Grated Aonla (50 \%) with Pineapple Pulp (50 \%) & 4.31 & 4.28 & 4.25 & 4.23 & 4.20 & 4.19 & 4.13 \\
\hline $\mathrm{T}_{6}=$ Grated Aonla $(60 \%)$ with Grape Must $(40 \%)$ & 4.28 & 4.27 & 4.24 & 4.21 & 4.18 & 4.14 & 4.10 \\
\hline $\mathrm{T}_{7}=$ Grated Aonla $(50 \%)$ with Grape Must (50\%) & 4.39 & 4.36 & 4.32 & 4.30 & 4.27 & 4.25 & 4.22 \\
\hline C.D. & 0.039 & 0.055 & 0.038 & 0.046 & 0.042 & 0.046 & 0.073 \\
\hline S.Em \pm & 0.010 & 0.014 & 0.010 & 0.012 & 0.011 & 0.012 & 0.019 \\
\hline $\mathrm{F}$ test & $* *$ & $* *$ & $* *$ & $* *$ & $* *$ & $* *$ & $* *$ \\
\hline
\end{tabular}

** Significant at $1 \%$

NS - Non Significant

Table.4 Effect of different fruit pulp ratio on total sugars (\%) content of blended beverages during storage period

\begin{tabular}{|c|c|c|c|c|c|c|c|}
\hline TREATMENT & 0 Days & 15 Days & 30 Days & 45 Days & 60 Days & 75 Days & 90 Days \\
\hline $\mathrm{T}_{1}=$ Grated Aonla $(100 \%)-($ Control $)$ & 5.55 & 5.51 & 5.46 & 5.42 & 5.39 & 5.35 & 5.28 \\
\hline $\mathrm{T}_{2}=$ Grated Aonla $(60 \%)$ with Sapota Pulp (40\%) & 5.75 & 5.71 & 5.68 & 5.62 & 5.57 & 5.54 & 5.47 \\
\hline $\mathrm{T}_{3}=$ Grated Aonla (50 \%) with Sapota Pulp (50 \%) & 7.10 & 7.04 & 7.01 & 6.99 & 6.93 & 6.88 & 6.79 \\
\hline $\mathrm{T}_{4}=$ Grated Aonla $(60 \%)$ with Pineapple Pulp (40 \%) & 7.47 & 7.44 & 7.41 & 7.35 & 7.30 & 7.26 & 7.19 \\
\hline $\mathrm{T}_{5}=$ Grated Aonla $(50 \%)$ with Pineapple Pulp (50 \%) & 7.88 & 7.84 & 7.80 & 7.77 & 7.74 & 7.72 & 7.65 \\
\hline $\mathrm{T}_{6}=$ Grated Aonla (60 \%) with Grape Must (40\%) & 7.20 & 7.18 & 7.14 & 7.11 & 7.07 & 7.03 & 6.98 \\
\hline $\mathrm{T}_{7}=$ Grated Aonla (50 \%) with Grape Must (50 \%) & 8.10 & 8.06 & 8.01 & 7.97 & 7.93 & 7.90 & 7.85 \\
\hline C.D. & 0.037 & 0.040 & 0.029 & 0.041 & 0.031 & 0.043 & 0.031 \\
\hline S.Em \pm & 0.009 & 0.010 & 0.007 & 0.010 & 0.008 & 0.011 & 0.008 \\
\hline F test & $* *$ & $* *$ & $* *$ & $* *$ & $* *$ & $* *$ & $* *$ \\
\hline
\end{tabular}

** Significant at $1 \%$

NS - Non Significant 
Table.5 Effect of different fruit pulp ratio on total phenols ( $\mathrm{mg}$ gallic acid equivalents $100 \mathrm{ml}^{-1}$ ) content of blended Beverages during storage period

\begin{tabular}{|c|c|c|c|c|c|c|c|}
\hline TREATMENT & 0 Days & 15 Days & 30 Days & 45 Days & 60 Days & 75 Days & 90 Days \\
\hline $\mathrm{T}_{1}=$ Grated Aonla $(100 \%)-($ Control $)$ & 976.38 & 936.06 & 888.96 & 833.02 & 771.33 & 758.40 & 716.93 \\
\hline $\mathrm{T}_{2}=$ Grated Aonla $(60 \%)$ with Sapota Pulp $(40 \%)$ & 923.90 & 893.70 & 856.96 & 825.34 & 752.90 & 748.67 & 702.98 \\
\hline $\mathrm{T}_{3}=$ Grated Aonla (50 \%) with Sapota Pulp (50 \%) & 861.44 & 833.41 & 800.38 & 770.82 & 718.46 & 706.94 & 653.06 \\
\hline $\mathrm{T}_{4}=$ Grated Aonla $(60 \%)$ with Pineapple Pulp (40 \%) & 833.41 & 797.18 & 742.66 & 703.74 & 674.94 & 661.89 & 623.23 \\
\hline $\mathrm{T}_{5}=$ Grated Aonla (50\%) with Pineapple Pulp (50\%) & 821.50 & 771.07 & 717.57 & 680.58 & 648.45 & 635.14 & 602.75 \\
\hline $\mathrm{T}_{6}=$ Grated Aonla $(60 \%)$ with Grape Must (40 \%) & 895.87 & 864.64 & 832.77 & 808.58 & 732.67 & 727.17 & 687.87 \\
\hline $\mathrm{T}_{7}=$ Grated Aonla $(50 \%)$ with Grape Must (50 \%) & 806.66 & 758.40 & 692.61 & 640.00 & 608.26 & 602.37 & 582.27 \\
\hline C.D. & 12.662 & 3.693 & 5.250 & 4.881 & 3.350 & 3.731 & 3.152 \\
\hline S.Em \pm & 3.240 & 0.945 & 1.343 & 1.249 & 0.857 & 0.955 & 0.807 \\
\hline F test & $* *$ & $* *$ & $* *$ & $* *$ & $* *$ & $* *$ & $* *$ \\
\hline
\end{tabular}

** Significant at $1 \%$

NS - Non Significant

Table.6 Effect of different fruit pulp ratio on total antioxidants (mg AAE $100 \mathrm{ml}^{-1}$ ) content of blended beverages during storage period

\begin{tabular}{|c|c|c|c|c|c|c|c|}
\hline TREATMENT & 0 Days & 15 Days & 30 Days & 45 Days & 60 Days & 75 Days & 90 Days \\
\hline $\mathrm{T}_{1}=$ Grated Aonla $(100 \%)-($ Control $)$ & 457.49 & 442.31 & 438.76 & 429.05 & 415.79 & 400.36 & 391.71 \\
\hline $\mathrm{T}_{2}=$ Grated Aonla $(60 \%)$ with Sapota Pulp (40 \%) & 427.43 & 411.14 & 409.33 & 390.37 & 385.73 & 379.59 & 371.68 \\
\hline $\mathrm{T}_{3}=$ Grated Aonla (50 \%) with Sapota Pulp (50 \%) & 400.21 & 389.07 & 384.27 & 377.39 & 362.63 & 347.53 & 333.16 \\
\hline $\mathrm{T}_{4}=$ Grated Aonla $(60 \%)$ with Pineapple Pulp (40 \%) & 412.80 & 402.02 & 387.89 & 383.37 & 379.20 & 369.87 & 357.48 \\
\hline $\mathrm{T}_{5}=$ Grated Aonla $(50 \%)$ with Pineapple Pulp (50 \%) & 396.15 & 387.97 & 378.69 & 362.12 & 348.90 & 341.55 & 323.92 \\
\hline $\mathrm{T}_{6}=$ Grated Aonla $(60 \%)$ with Grape Must $(40 \%)$ & 408.71 & 386.99 & 382.42 & 376.17 & 368.81 & 358.78 & 343.36 \\
\hline $\mathrm{T}_{7}=$ Grated Aonla (50 \%) with Grape Must (50 \%) & 390.80 & 383.68 & 375.38 & 367.47 & 340.36 & 323.17 & 307.63 \\
\hline C.D. & 2.755 & 2.428 & 2.979 & 1.715 & 3.218 & 2.805 & 4.000 \\
\hline S.Em \pm & 0.705 & 0.621 & 0.762 & 0.439 & 0.823 & 0.718 & 1.024 \\
\hline$F$ test & $* *$ & $* *$ & $* *$ & $* *$ & $* *$ & $* *$ & $* *$ \\
\hline
\end{tabular}

** Significant at $1 \%$

NS - Non Significant 
Table.7 Effect of different fruit pulp ratio on alcohol (\%) content of blended beverages during storage period

\begin{tabular}{|c|c|c|c|c|c|c|c|}
\hline TREATMENT & 0 Days & 15 Days & 30 Days & 45 Days & 60 Days & 75 Days & 90 Days \\
\hline $\mathrm{T}_{1}=$ Grated Aonla $(100 \%)-($ Control $)$ & 3.90 & 3.96 & 4.01 & 4.05 & 4.09 & 4.12 & 4.16 \\
\hline $\mathrm{T}_{3}=$ Grated Aonla $(50 \%)$ with Sapota Pulp (50 \%) & 3.85 & 3.91 & 3.95 & 3.99 & 4.02 & 4.06 & 4.09 \\
\hline $\mathrm{T}_{5}=$ Grated Aonla (50\%) with Pineapple Pulp (50\%) & 3.59 & 3.66 & 3.73 & 3.80 & 3.87 & 3.93 & 3.98 \\
\hline $\mathrm{T}_{6}=$ Grated Aonla $(60 \%)$ with Grape Must (40 \%) & 3.37 & 3.48 & 3.55 & 3.63 & 3.69 & 3.72 & 3.76 \\
\hline $\mathrm{T}_{7}=$ Grated Aonla $(50 \%)$ with Grape Must $(50 \%)$ & 2.95 & 3.03 & 3.09 & 3.15 & 3.22 & 3.26 & 3.29 \\
\hline F test & $* *$ & $* *$ & $* *$ & $* *$ & $* *$ & $* *$ & $* *$ \\
\hline
\end{tabular}

Fig.2 Sensory evaluation of the blended beverages

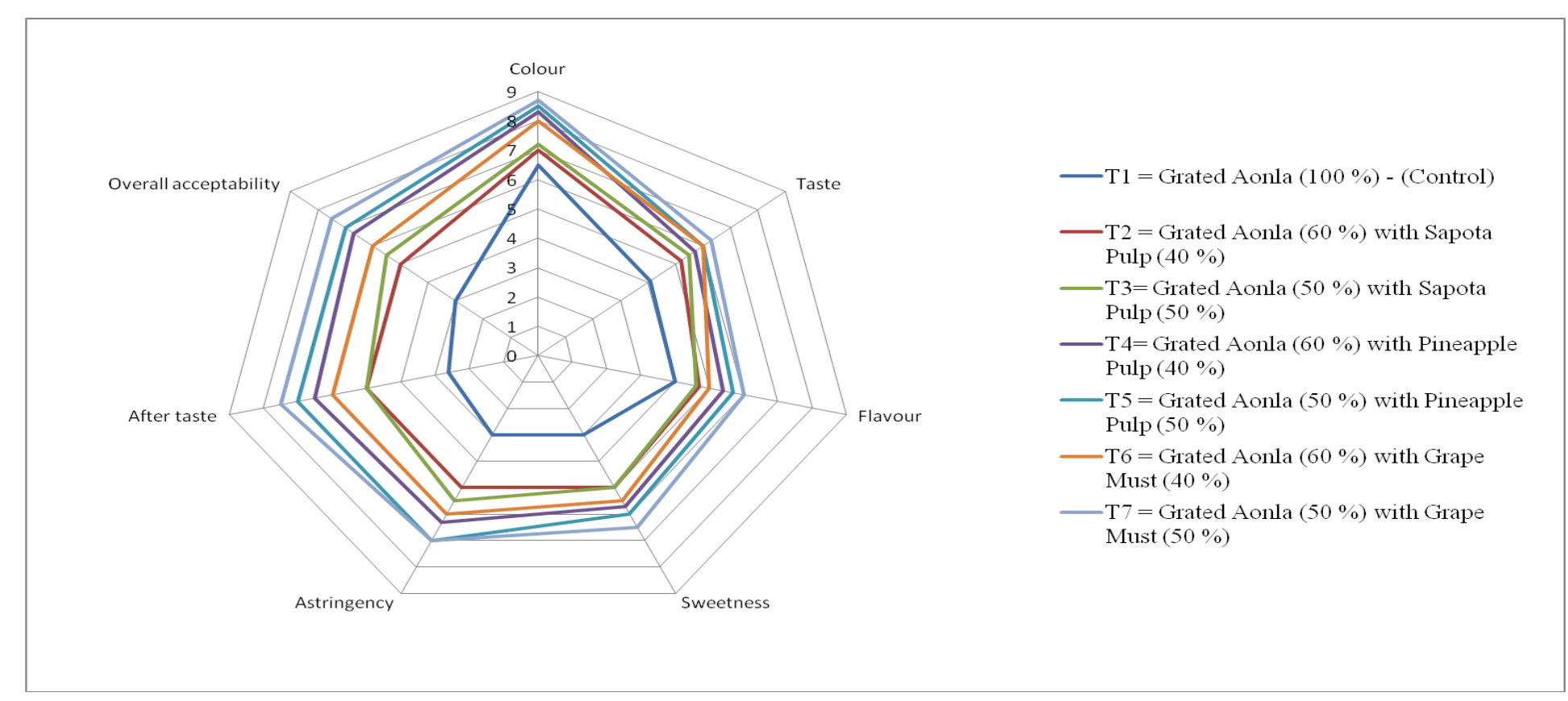




\section{Total antioxidant (mg AAE $100 \mathrm{ml}^{-1}$ )}

The decreasing trend in the antioxidant content was observed in storage time. The antioxidant content was found highest in the Treatment 1[Grated Aonla (100 per cent Control)]. There was significant difference between the treatments with respect to antioxidant. The lowest level of antioxidant was observed in the Treatment 7 [Grated Aonla (50 \%) with Grape Must (50 \%)] (Table 6).

\section{Alcohol (\%)}

The increasing trend in the alcohol content was observed in storage time. There was significant difference between the treatments with respect to alcohol content in blended beverages. The alcohol content (4.16) was found to be significantly highest in the treatment $\mathrm{T}_{1}$ - Grated Aonla (100 per cent Control). The lowest alcohol percentage (3.29) was observed in the treatment $T_{7}$ Grated Aonla (50 \%) with Grape Must (50 $\%)$. Similar results was reported by Chikkasubbanna et al., (1990), that the alcohol percent of the grape wine increased due to decrease in total soluble sugars due to the activity of yeast during fermentation. Adusule et al., (1992) estimated the alcohol content in pomegranate wine and reported that upon incubation alcohol content (6.6 per cent) was increased and Sapna et al., (2002) obtained an alcohol content of 6.57 to 6.75 per cent in Japanese wine, coriander wine had 7.05 to 7.37 per cent in the third and after nineth weeks of storage. The increase in alcohol content was due to the complete conversion of sugars to alcohol. The variation in alcohol production by yeast strains may be due to the variation in the rate of sugar utilization during fermentation and alcohol tolerance limits. The reduction in the sugar level indicated that some sugar content has been consumed by the yeast as a substrate to grow and converted to ethanol. (Singh and Preetinder Kaur, 2009) (Table 7).

Treatment $\mathrm{T}_{7}$ [Grated aonla $(50 \%)$ with Grape must (50\%)] was found to be best when compared to all the other treatment and followed by Treatment $\mathrm{T}_{5}$ (Grated Aonla [50 $\%)$ with Pineapple Pulp (50\%)] which was second best treatment as compared to other treatments. Whole aonla fruits can be utilised for fermentation and here the phenolic content may decrease and clarity of beverage can be obtained with better taste.

\section{References}

Adsule, R. N., Kotecha, P. M., and Kadam, S.S., 1992. Preparation of wine from pomegranate. Beverage Food World, 19(4):113-114.

Adsule, R. N., Patil, B.S., and Chavan, U. D., 1995. Influence of Sulphur dioxide levels and $\mathrm{pH}$ of the must on the quality of pomegranate wine. Beverage Food World, 24(4): 28-30.

Attri, B. L., 2009. Effect of initial sugar concentration on the physic - chemical characteristics and sensory qualities of cashew apple wine. Natural Product Radiance, 8(4): 374-379.

Augustin, A., 1987. Fermented product of cashew apple, Cashew bulletin, 24(7):12-17.

Benzie, I. F. F., and Strain, J. J., 1996. The ferric reducing ability of plasma (FRAP) as a measure of antioxidant power: The FRAP assay. Analytical Chemistry, 239:70-76.

Bravo- Abad, F., and Inigo-Leal, B., 1989. Biochemical and technological aspects of the biological ageing of Extremadura white wine. Alimentaria, 204: 43-46.

Caputi, A., Ueda, M., and Brown, M.T., 1968. Spectrophotometric determination of ethanol in wine. The American Journal of Enology and Viticulture. 19:160-165 
Chikkasubbanna, V., Chadha, K.L., Ethiraj, S., 1990. Influence of maturity of Thomson Seedless grapes on the wine composition and quality. Indian Journal of Horticulture, 47: 12-17.

Matapathi, S. S., 2002. Screening of wine yeasts and pomegranate (Punica granatum L.) cultivars for wine production. M. Sc. (Agri.) Thesis, University of Agricultural Sciences, Dharwad, Karnataka.

Olasupo, N.A., and Obayori, O.S., 2003. Utilization of palm wine (Elaeis guinensis) for the improved production of Nigerian indigenous alcoholic drink Ogogoro. Journal of Food Processing and Preservation, 27: 365-372.

Panse, and Sukhatne, 1978. Statistical methods for agricultural workers. Indian Council of Agricultural Research, New Delhi.

Patil, D.S., 1994. Studies on preparation of wine from commercially grown varieties of grape (Vitis vinifera L.). M. Sc. (Agri.) Thesis, Mahatma Phule Krishi Vidyapeeth, Rahuri, Dist. Ahmednagar, Maharashtra.
Ranganna, S., 1986. Handbook of analysis and quality control for fruits and vegetable products. 2nd ed., Tata McGraw-Hill Publishing Co. Ltd. New Delhi.

Sapna, V., Vasundhara, M., and Annapurna, M. L., 2002. Fermented beverages from spices- a nutraceutical drink. Journal of Spices and Aromatic Crops. 11: 106111.

Singh, and Preetinder Kaur, 2009. Evaluation of litichi juice concentrates for the production of wine. Natural Product Radiance, 8(4): 386-391.

Singleton, V. L., and Rossi, J. A. 1965. A colorimetry of total phenolics with phosphomolybdic-phosphotungstic acid reagents. The American Journal of Enology and Viticulture, 16:144-158.

Taskar, N. V., 2007. Effect of different levels of diammonium hydrogen phosphate, sulphur dioxide and dilution on yield and quality of jamun (Syzigium cuminii Linn.) wine. M. Sc. (Agri.) Thesis, Dr. Balasaheb Sawant Konkan Krishi Vidyapeeth, Dapoli. Dist. Ratnagiri, Maharashtra.

\section{How to cite this article:}

Chirag Reddy, M., K.N. Sreenivas, G.S. Manjula, M. Karan and Mohamad Tayeeb Ulla, H. 2017. Aonla (Emblica officinalis Gaertn.) Based Fermented Beverages. Int.J.Curr.Microbiol.App.Sci. 6(10): 4740-4749. doi: https://doi.org/10.20546/ijcmas.2017.610.440 